\title{
Spirituality and Dogmatism: Social Implications of Dogmatism and Its Cure
}

\author{
Mrs. Irina Dwarak \& Dr. Anuviyan \\ (Vedanta Cultural Foundation, Pune, India - A Scientific \& Industrial Research Organisation (SIRO) \\ recognised by the Ministry of Science \& Technology, Government of India)
}

\begin{abstract}
The study defines "spirituality" and "dogmatism". It explores dogmatism in relation to spirituality. The primary hypothesis of the paper is that spirituality per se cannot be considered a cause of dogmatism. The paper analyzes dogmatism as a social phenomenon and inquires into its root causes. It further investigates into the social implications of dogmatism and examines its various manifestations and effects such as narrowing of ideas and social alienation, authoritarianism and sectarianism, intolerance and conflicts. The study examines the ways to eradicate dogmatism through liberal spiritual education. It highlights the importance of development of the human intellect as an antidote to dogmatism. Methods of strengthening the intellect are discussed.
\end{abstract}

Key Words: Spirituality, dogmatism, intellect, narrowing of ideas, authoritarianism, intolerance, liberal education.

\section{Introduction}

The fundamental works Sociology of Religion by Max Weber and The Elementary Forms of Religious Life by Emile Durkheim brought the study of spirituality into the focus of social science. However, even before these works appeared, the comparative studies of various spiritual traditions undertaken by James Frazer and Edward Tylor established that spirituality was a cultural phenomenon, and no longer peripheral to the study of a human society [1].

In this study the term "spirituality" refers to the striving of individuals or groups of people towards self-development culminating in Self-realization. Spirituality denotes a "subjective experience of the sacred" [2, p.550]. A. Parthasarathy defines spirituality as a "technique of discovering your supreme Self within" [3, p.264]. The Self is the Transcendental Reality which lies beyond the three known realms of waking, dream and deepsleep. It is the Fourth state of pure, unconditioned Consciousness, referred to by laymen as Spirit or God. Spirituality is an individual phenomenon which may or may not take the form of an institutionalized religion involving church, temple or mosque attendance, organized rites and rituals, prayer and worship.

In spite of being a deeply personal creation of individuals, spirituality is a social phenomenon which contributes to meeting the functional prerequisites of society. A healthy and prosperous society requires a certain degree of social solidarity, a sense of identity as well as value consensus. Spirituality caters to these basic needs of a society and functions as a means of social cohesion. Spirituality enables people to be socially conscious and charitable, truthful, forgiving, cheerful, peace - loving, compassionate and open-minded. These values are not only proved by time, but also based on reason. They provide certainty and order to an otherwise anarchic society and function as a socially integrative power. Such values create ethical frameworks serving as guidelines and standards for human actions.

Talcott Parson argues that spirituality provides meaning to contradictory and threatening events in social life such as evil, suffering and death. Spirituality helps to "make sense" of these events in terms of an integrated and consistent pattern of meaning. This allows intellectual and emotional adjustment and promotes order and stability individually and collectively. Numerous studies link spirituality to social health and harmony [4]. Thus spirituality is an integrating and unifying force in the human society.

Spirituality has two main components: 1. philosophy, knowledge of higher values - to cater to the intellectual aspect of one's personality, 2. devotional practices - to cater to the emotional aspect of one's personality. When the philosophical aspect of spirituality is neglected and the thinking capacity deteriorates, dogmatic beliefs unsupported by evidence, reason and logic, emerge. The ignorance of higher values results in emergence of opinionated beliefs which are held blindly, with unreasoned passion and intensity. Hence, without knowledge and reasoning, spirituality degenerates into dogmatism.

In Palgrave Macmillan Dictionary of Political Thought $[5$, n.p.] dogmatism is defined as "the tendency to treat one's own beliefs, whatever their origin and nature, as matters of dogma, and so to hold on to them irrationally, in the conviction that one's standpoint depends in its entirety on their preservation. More widely, the inability to relinquish some conviction, in the face of however much evidence to the contrary. Dogmatism 
implies a belief in a doctrine, which gives system to all beliefs, and so shows each belief to be immovable" Hence, dogmatism is an uncritical, partial and irrational persistence of some opinion. It is a relatively unchangeable and unjustified conviction. According to Rokeach dogmatism is closed-mindedness. He defines dogmatism as a relatively closed system of beliefs or disbeliefs about reality, which is organized around a central set of beliefs about absolute authority and which in turn provides a framework for intolerance or qualified tolerance of others [6, p.249].

A person is considered dogmatic when he asserts his opinion authoritatively and possesses no tolerance towards the views of others. According to Mander a dogma is "a pronouncement by somebody who does not state his grounds or offer any proof, but relies upon "prestige" (authority) to secure acceptance of his views without question" [7, p.128]. From a psychological perspective, dogmatism is based on a certainty "I am right and everybody else is wrong." A dogmatic person seldom, if ever, admits that he is wrong. However, this certainty with respect to one's own views is unjustified. Such a person is characterized by an exceptional stubbornness with which he adheres to his views and ideas. Dogmatism is not necessarily only an individual, but also a collective phenomenon. A dogmatic statement could be passed from person to person, from generation to generation. It may be a part of a traditional belief or a social inheritance of a particular group of people.

Dogmatism presents a direct threat to social order. It is a divisive and disruptive force which polarizes and destabilizes society. It can take the form of a fanatic attachment to one's own idea, belief or concept and metamorphose into a source of innumerable social problems such as sectarianism, fundamentalism, fanaticism, intolerance, conflicts and religious militancy. The history of religion may be viewed as the history of persecution due to dogmatism.

This study explores dogmatism in relation to spirituality. The primary hypothesis of the paper is that spirituality per se cannot be considered a cause of dogmatism. The paper analyzes dogmatism as a social phenomenon and inquires into its root causes. It further investigates into the social implications of dogmatism and examines its various manifestations and effects such as narrowing of ideas and social alienation, authoritarianism and sectarianism, intolerance and conflicts. The study discusses the ways to eradicate dogmatism through liberal spiritual education and development of the human intellect.

\section{Root Causes of Dogmatism}

Dogmatism is synonymous with attachment, mental involvement or bondage to a particular idea, belief or value. Human being is constituted of the body, mind and intellect. The body is driven into actions by either the mind or the intellect. Mind is indiscriminate. It entertains likes and dislikes, wishes and wants. Intellect is the capacity to think, to discriminate. Intellect is different from intelligence, which relates to ideas and information received from external sources such as teachers and textbooks, schools and universities. By gaining information from these sources a person becomes informed, knowledgeable. Thereby, he can make a living. However, the intellect is the capacity to think independently, without bias and prejudice. The functions of the intellect are to judge, weigh the pros and cons, draw conclusions and apply knowledge. Intellect is a faculty of questioning, enquiring, not taking anything for granted. A strong intellect ensures clear, precise thinking and sound reasoning. When the intellect is not sufficiently developed, it is weak and dull. Hence, it cannot exercise control over the indiscriminate thought flow from the mind. When the initial thought flow is not supervised by the intellect, it becomes thicker and stronger developing into attachment. Thus, the root cause of dogmatism is the lack of development of the intellect. In the words of William James, "Spiritual excitement takes pathological forms whenever other interests are too few and the intellect too narrow" [8, p.39].

The formation of dogmatic beliefs often takes place in early childhood. Since the intellect is not yet sufficiently developed in a child, he adopts a belief system uncritically. Later on, in adult life, it becomes a regular pattern of thought which he finds very difficult, almost impossible to question. Such beliefs seem obviously true. By the age of 14-15 one proclaims he is a Hindu, Christian or Muslim with hardly any foundation for such assertion, sans intellectual analysis. When the child grows up, he tends to accept only such new ideas as fit in with the ideas he already holds; and all conflicting ideas seem 'obviously' absurd.

Without intellectual application spirituality is converted into a blind adherence to dogmas and doctrines. A person attached to his views and ideas, holds on to them stubbornly and blindly, in spite of or contrary to evidence. According to Rokeach, "it is commonly observed that relatively dogmatic views on specific issues are stubbornly resistant to change by logical argument or objective evidence" [9, p.13].

A weak intellect is hardly capable of questioning. Moreover, dogmatic religionists stifle the attitude of enquiry and questioning in seekers. Xavier observes: "The individual is actively discouraged or prevented from pausing and pondering" [8, p.69]. According to Seaman, "very often participation in a fundamentalist religious group involves formation and reinforcement of closed belief systems. Such groups are likely to encourage dogmatism by rewarding their members with approval and / or the promise of heaven for holding their beliefs unquestionably" [10, p.254]. Hence, masses passively accept religious dogmas, just because they belong to an 
ancient tradition or are followed by vast numbers, or come from a prominent personality. They follow the line of their predecessors lacking intellectual discernment.

To grasp the profound message of the scriptures a spiritual aspirant needs to reflect and contemplate upon them. When the intellect is weak and reflection virtually absent, the message embedded in the sacred texts cannot be absorbed and assimilated. Due to intellectual deficiency, the ancient texts are read mechanically, without application of reason. In the words of A. Parthasarathy: "In India, religious pundits boast of a mechanical mastery over Sanskrit language, grammar and construction. They merely memorise and recite countless verses of the language hardly understood by anyone. They learn to quote, twist and torture the old Sanskrit texts. And claim superiority over spiritual seekers who pursue the truth with original thinking and free reasoning" [3, p. 57]. As a result, limited opinions and interpretation emerge. They replace eternal scriptural truths.

Such a mechanical approach to the scriptural literature leads to literal interpretations which in turn result in serious misapprehensions of the original message. For instance, practitioners the world over firmly adhere to a dogmatic belief that their religion alone can save humanity. According to the Encyclopedia of Community [11], up to $89 \%$ of various denominations and sect members believe that only their religion is legitimate This dogmatic notion is partly based on the misconception which arose from the usage of personal pronouns "I" and "Me" by some spiritual Masters. For instance, the following words are attributed to Christ: "Let the little children come to me and do not hinder them, for to such belongs the kingdom of heaven" (Matt. 19:14, English Standard Version) Lord Krishna proclaims in the Bhagavad Gita: "Fix your mind on Me, be devoted to Me, sacrifice to Me, bow down to Me; thus uniting yourself to Me, taking Me as the supreme Goal, you shall come to Me" (IX:34) [12, p.480]. Only a seeker who applies his intellect understands that when Masters use personal pronouns "Me" and "I", they do not refer to their own personalities, but to the universal Truth, the Self, or in layman's language - God, the Reality, with which they have completely identified.

Another typical example of a scriptural misapprehension is the concept of heaven employed by most religions. The vast majority of seekers understand "heaven" literally, as a geographical location a person goes to as a reward for meritorious deeds. One requires a strong intellect to understand that heaven is not a geographical place but a symbol indicating an internal state of peace, happiness and tranquility when the mind is free from suffering, sorrow and agitations. The dogmas of heaven and hell, reward and retribution, are built around this misconception.

N. S. Xavier equates dogmatism and literalism. In his book The Two Faces of Religion he gives an account of an instance of such literal scriptural interpretation. The author describes his conversation with a dogmatic Christian minister. The minster claimed he can easily prove that Lord Krishna could not be a Divine person. Turning the pages of the Bible, he pointed out the passage that read "God is Light". The minister concluded that since Krishna is said to have had a dark complexion, he cannot be God. The minister had taken the statement literally, out of the general context of the Bible, disregarding the deeper philosophical import of the symbolic language of the scripture. Xavier observes that an interesting feature of a dogmatic person is the way he selects the most self-serving of the possible literal interpretations [8].

Without a developed intellect spiritual aspirants not only slip into literalism but also tend to give excessive importance to the non-essentials of religion and over-emphasize external aspects of religion such as rites and rituals. These are followed blindly without deeper understanding of their philosophical significance.

A.Parthasarathy summarizes the effects of non-thinking in spirituality as follows: "Religion has been reduced to mere maxim and mandate. Free thinking has been stifled, strangled. And people have lost their reason, their independent judgment. The natural growth in spirituality has been stunted by forced doctrine and dogma. The well-meaning custodians of religion have turned the masses into spiritual pygmies" [3, p.163].

\section{Manifestations and Effects of Dogmatism on Individual and Society}

The effects of dogmatism on an individual and society vary widely, depending on the extent of one's attachment to an idea or a belief. Dogmatism manifests at personal as well as collective levels as: intellectual closed-mindedness, incapacity to absorb new ideas, denial of freedom of thought to oneself and others, clannishness and authoritarianism. As the degree of one's involvement with ideas and beliefs increases, dogmatism takes the shape of intolerance and fanaticism resulting in militancy and separatism, wars and conflicts.

\section{1. "Narrowing"}

To describe the manifestations of dogmatism at the institutional and non-institutional levels Rokeach coined the word "narrowing" [9, p.13]. The term denotes the phenomenon of avoiding contact with various stimuli such as books, people, events, new ideas etc., which threaten the validity of one's dogmatic belief.

At the institutional level, narrowing may manifest as a removal and burning of books that are considered dangerous; ostracizing or eliminating those regarded as blasphemous; conscious or unconscious re- 
writing of history [9]. Such narrowing is often employed by totalitarian authorities and systems. It amounts to the denial of freedom to think, choose and act independently. History provides plenty of instances of this manifestation of dogmatism. For example, there has been a perennial conflict between science and dogmatic church authorities, which have tried time and again to interfere with the free inquiry of scholars and suppressed the advance of science out of fear that scientific discoveries may well undermine the validity of Biblical statements. Thus, Galileo, in the mid-seventeenth century, was forced by the church to publicly recant the Copernican theory that the earth, along with other planets, revolves around the sun, and accept the medieval religious cosmology, which placed the earth at the centre of the universe. Those who refused to conform to the official dogma were considered heretics and faced punishment by Inquisition. Not only were books destroyed by fire, but also those considered blasphemous were burnt at the stake. The well-known example is the execution of Giordano Bruno.

Likewise, the theory of evolution was officially repudiated by both Protestants and Catholics. Sumner and Keller write: "It is as difficult to find any type of religion which welcomed free enquiry as it is easy to cite eminent inquirers who have been executed or persecuted by religious authorities" [13, p.680]. Till today Christian dogmatists reject the discoveries of biology and physics about the origins of life and insist that the Book of Genesis is scientifically sound in every detail.

At the personal level, narrowing may become apparent from the systematic restriction of one's activities in order to avoid contact with people, books, ideas involving other religions. At the same time it is marked by a selective choice of books, friends and associates solely on the basis of compatibility of religious views. Such narrowing causes one to avoid social contact with those adhering to different belief systems. Henceforth, it brings about clannishness and alienation from others.

Apart from that, narrowing manifests as an inability to receive and absorb new information. When new information becomes available, a dogmatist rejects it outright if it does not fit into his existing pattern of thinking. For instance, Christian dogmatists vehemently rejected revolutionary ideas of Darwin and Freud. A dogmatic person is partial and prejudiced. He is unwilling to learn something new or to re-learn what he already knows. Due to attachment to one's own ideas and resistance to change, a dogmatist cannot receive knowledge or be educated on higher values. Such a person cannot be taught or corrected. Hence, he remains in ignorance.

The inability to absorb new ideas is intensified by the uncompromising attitude, "I am right and everybody else is wrong". The more dogmatic a person is, the more pronounced will be this attitude. A dogmatist tends to vehemently insist on his own point of view, to argue and retaliate. Such an attitude leads to an inevitable failure in inter-personal relationships since it leaves no room for compromise and adjustment. It is always accompanied by the sense of exclusiveness and absolutism.

\subsection{Authoritarianism and Sectarianism}

Another manifestation of dogmatism is authoritarianism. A dogmatist relies excessively on authority to provide guidance and make decisions since, as mentioned above, he has a poor ability to evaluate information on its own merits, to judge, question and analyze. Xavier remarks: "The person with a closed mind tries to overcome insecurity and self-hate by over-identifying with the authority figure. This is different from accepting a great person as one's ideal or one's model to follow" [8, p.122]. According to Rokeach, "with increase in dogmatism there will be increasing admiration and glorification of those perceived in a position of authority. Apart from that, there will be increasing fear, hatred and vilification of those perceived in position opposed to positive authority" [9, p.17].

A characteristic trait of an authoritarian system is the primacy of doctrines and dogmas over the personality. According to Robert Lifton an authoritarian system demands "that character and identity be reshaped, not in accordance with one's special nature or potentialities, but rather to fit the rigid contours of the doctrinal mould" [14, n.p.]. Authoritarianism goes hand in hand with sectarianism. Sectarianism is "the tendency of people to believe that their religion is superior to all others. The term also can refer to the process by which religious organizations split apart into competing fragments, and to the social factors that maintain the separateness of each group. Thus, sectarianism is associated with the fragmentation of society, even as it creates a relatively cohesive religious community in each particular sect or denomination" [11, n.p.]. Sect leaders are often charismatic and authoritarian figures who wield absolute power over followers. They closely control and monitor their members. Xavier observes: "Cults exploit individuals and pose a danger to society. Members of many cults are ready and willing to go to any extremes to protect their power and position" [8, p.186].

In an authoritarian and sectarian environment there is a strong tendency towards blind obedience and anti-intellectualism. Unconditional reverence for the leader and his teaching is encouraged. A single cause or a single ideology is fanatically promoted in a cult; doubts and questions about it are suppressed, even persecuted. The unquestioned acceptance of a dogma is ensured through promises of eternal reward and salvation as well as through cultivation of guilt, blame and fear of the wrath of God. A dogmatist tends to take whatever the 
authority says for granted and is often "taken for a ride" or manipulated by those in position of power and authority.

Conformity in thinking is actively enforced by authoritarian sect leaders. George Estabrooks remarks: "(The cult leader) will strive for a restriction of the field of consciousness among the members of his mob (cult).... His ideas, and his ideas only, are to be considered by the mob (cult).... His followers hear only one line of thought, his line of thought" [14, n.p.]. Robert Lifton describes the language of the authoritarian environment as a "thought-terminating cliché", a "language of non-thought" [14, n.p.]. Lifton states: "The effect of the language of ideological totalism can be summed up in one word: constriction. He is, so to speak, linguistically deprived; and since language is so central to all human experience, his capacities for thinking and feeling are immensely narrowed" [14, n.p.].

Religious sects and cults set themselves apart from a society. The rejection of social environment creates a three dimensional tension: cultural difference, social separation and psychological antagonism [11]. Conversion into a cult is accompanied by an emotional and physical distancing from family and friends or even a complete cut off from past relationships, positions and occupations. Cults employ various techniques of conversion. According to Wakefield [14, n.p.] : "These techniques include constant repetition of doctrine, application of intense peer pressure, manipulation of diet so that critical faculties are adversely affected, deprivation of sleep, lack of privacy and time for reflection, complete break with past life, reduction of outside stimulation and influences, the skillful use of ritual to heighten mystical experience, and the invention of new vocabulary and the manipulation of language to narrow down the range of experience and construct a new reality".

Willa Appel describes a three-stage conversion into a cult: 1 . The individual is isolated from his past life by severing all emotional ties. 2 . The initiate loses his former name and identity. This is reinforced by inducing the novice, emotionally and intellectually, to surrender his past life. Humiliation and guilt are the basic tools of conversion at this stage. 3. In the third phase, "the convert assumes a new identity and a new world view" [14, n.p.]. Margery Wakefield observes in her book "Understanding Scientology" that conversion is accomplished "through a rigorous process of indoctrination through written and tape-recorded materials. The member's confidence in all previously trusted social institutions is ended, and replaced with the belief that salvation can come only through Scientology. The person's new sense of identity comes from his or her belonging to the cult as all other allegiances are severed" [14, n.p.].

Sects can pose danger to their own members, too. This became obvious in November $18^{\text {th }} 1978$ when Reverend James Warren Jones and his 913 followers who constituted the People's Temple cult committed mass suicide. Thus dogmatic closed-mindedness, accompanied by a blind submission to an authoritarian figure or a cult leader, manifests as disturbed patterns of thought and behavior which impede one's psychological, spiritual and social development and healthy social life.

\subsection{Intolerance and Conflicts}

Attachment in any religion leads to disparity, separatism and conflict. Extreme attachment to an idea or ideology creates defensive psychology in an individual when he or she experiences a strong need to protect it at any cost against external factors. This is the reason why dogmatic persons often have an outlook of threat towards the world which in turn breeds intolerance, aggression and even militancy.

Dogmatism and feeling of threat reinforce each other. The greater the dogmatism, the stronger is the feeling of threat and anxiety experienced by an individual and vice versa. Rokeach's studies established a link between the rise in dogmatism and threatening situations. These studies show that those who scored high on dogmatism scales were also the ones who scored high on anxiety scales [10]. The evaluation of a dozen ecumenical councils of the Catholic Church showed that the more the institution felt threatened by the external circumstances, the more absolute and prohibitive were the canons, policies and dogmas enacted by the council [10].

A dogma is usually accompanied by some kind of threat and attempts to ostracize those who do not think alike. Mander writes in his book Clearer Thinking: "We shall nearly always find that a belief rests on no reasonable grounds, but on dogma alone, whenever it is delivered with an accompaniment of warnings and threats - that those who do not believe will be damned; or will be dismissed, ostracized, or in some way persecuted; or will be regarded by the 'powers that be' as wicked and immoral, or un-British and disloyal" [7, p.128].

The thinking of a dogmatic person is dichotomous. He develops an increasingly polarized distinction between the faithful and unfaithful, orthodoxy and heresy, friend and enemy. This leads to adaptive inflexibility and sense of exclusiveness. The greater the dogmatism the less is the willingness to compromise with and to accommodate adherents of other belief systems. Those who disagree with a doctrine are rejected as the enemies of God, even persecuted. Their faith and spiritual values are easily misconstrued and misinterpreted. Extreme dogmatism manifests as a belief that one should not compromise with one's 'enemies'. Compromise is 
perceived as synonymous with appeasement. A dogmatist believes that he must be constantly on guard against subversion from within and without. Thus, a dogmatic person creates for himself an exclusive identity and views others with contempt and hatred.

Those who agree with one's own belief system are accepted; however, only on condition that they continue to do so. Rokeach refers to such acceptance as "qualified tolerance" which is in fact nothing but "another form of intolerance" [9, p.18]. This is often seen in an especially harsh attitude towards the renegade from the cause. For instance, in Scientology there are two types of "nonpeople": the so - called "wogs" and "SPs." "Wogs" are those who are yet to be converted to Scientology. And "SPs" are suppressive persons with no right to exist since they have rejected the tenets of the doctrine. Such people are considered enemies. They can be "sued, tricked, lied to or destroyed" [14, n.p.].

The extreme manifestation of dogmatism is fanaticism. It arises when one's attachment to a belief system, a sense of exclusiveness, antagonism and fear reaches maximum expression. Hatred, destructiveness and militancy are essential features of fanaticism. Fanaticism in spiritual field promotes ignorance and restricts knowledge. As an extreme form of attachment, fanaticism springs from the deficiency of the human intellect.

William Nicholls defines fanaticism: "Fanaticism, then, may perhaps be the characteristic of those who regard their religious or religio-political ends as justifying the use of means that would otherwise be forbidden. These means, slander, murder, and murder by suicide, are employed against other groups defined by the leaders of the fanatical group as enemies. On an emotional level, it seems that the fervor of their attachment to their religious object, deity or otherwise, leads them to hate correspondingly those identified as opponents of their own truth. Underlying fanaticism, therefore, is hate" [15, p.446].

Religious fanaticism is the root cause of many wars and aggressions which took place in the past and still go on all over the world. Human history is stained by Holy Wars of various magnitudes. Xavier observes: "Holy Wars are particularly vicious and prolonged. Participants in Holy Wars do not have the restraints of conscience since the religious cause takes care of any sense of guilt. The hope of instant salvation or even a special place in heaven and high honor on earth makes killing for one's religion extremely attractive. (...) Moreover, in being cruel to their enemies, religious fanatics are punishing God's enemies, sort of doing dirty work for God. (...) Furthermore, as Jerome Frank observed, Holy Wars have no natural end-points like other wars. Most wars are about control of the territory or power over others but in Holy Wars the struggle can go on until the other side is converted and destroyed. Often the fight goes on until both sides are exhausted" [8, p.112]. Apart from such obvious instances as Holy wars, there are innumerable other examples of intolerance and destructiveness at community, family and individual levels.

\section{Cure for Dogmatism is Development of the Intellect through Liberal Spiritual Education}

In the report on Learning for the $21^{\text {st }}$ Century American sociologist and writer Alvin Toffler remarked, "the illiterate of the $21^{\text {st }}$ century will not be those who cannot read and write, but those who cannot learn, relearn and unlearn" $[16$, p.]. As mentioned above, the characteristic of a dogmatic person is his inability to question, enquire, re-think and re-examine set beliefs and values. Hence, dogmatism can be viewed as a modern form of illiteracy. In order to restore literacy and culture in the society, the human intellect must be developed through liberal spiritual education.

In his book The Fall of the Human Intellect A. Parthasarathy [17] has described the four stages of intellectual development of mankind: Age of Perception, Age of Superstition, Age of Scientific Enquiry and Age of Contemplation. In the Age of Perception humans merely gaze upon the world without any internal reactions and responses. Their intellect is virtually absent. In the Age of Superstition people observe the world around them and try to correlate various occurrences. However, their intellect is too weak to establish correct cause and effect relationships. That is why superstitions, blind beliefs and dogmas emerge. The Age of Scientific Enquiry is characterized by the development of the gross intellect which recognizes that the world is governed by the Law of Causation. Those who belong to the Age of Enquiry apply their intellect to investigate into and comprehend the laws which control the macro- and microcosm. Such people are scientifically minded; they do not take anything for granted but rely on reason and logic. According to Bertrand Russell, the substitution of evidence for dogma as a basis for belief, is one of the greatest achievements that science has conferred upon mankind [18]. The acme of intellectual development is the Age of Contemplation, when people employ their subtle intellect, the capacity to distinguish the eternal from the ephemeral, spirit from matter, to contemplate upon the Transcendental Reality.

A dogmatist is one who belongs to the Age of Superstition. To eradicate dogmatic narrow-mindedness human beings must gradually train their intellect thus gradually evolving from the Ages of Perception and Superstition to the Ages of Scientific Enquiry and Contemplation.

A strong and sharp intellect is not something humans possess naturally, from birth. The intellect has to be built by oneself. In fact, one needs to invest a lot of effort over a sufficient period of time to acquire this skill. In words of A. E. Mander: "Thinking is a skilled work. It is not true that we are naturally endowed with the 
ability to think clearly and logically - without learning how, or without practicing. (...) People with untrained minds should no more expect to think clearly and logically than people who have never learnt and never practiced can expect to find themselves good carpenters, golfers, bridge-players or pianists" [7, p.vii].

Cultivation and strengthening of the human intellect is achieved through liberal spiritual education. Etymologically the word "education" is derived from two Latin words ex "to draw out from within" and ducere "to lead". Hence, "education" means "to lead out, to bring forth". Liberal education helps to draw the knowledge out of students instead of pushing it in.

In the mid-nineteenth century in his book The Idea of a University, Cardinal Newman coined the terms "liberal" and "servile" education. By liberal education he meant a "pursuit of knowledge for its own sake" [19, p.78] without the idea of trading with it, whereas servile education is education undertaken with utilitarian motives, i.e. for "vocational, mercenary or pecuniary purpose" [17, p.89]. According to Newman: "Liberal Education, viewed in itself, is simply the cultivation of the intellect, as such, and its object is nothing more or less than intellectual excellence" [19, p.92].

In 1868 the English biologist Thomas H. Huxley delivered a speech on "A Liberal Education" in London at the Working Men's College. He drew a parallel between a game of chess and human life. He compared the chess board to the world, the pieces to the phenomena of the universe and rules of the game to laws of Nature. According to Huxley, liberal education is "learning the rules of this mighty game". He defines liberal education as "the instruction of the intellect in the laws of Nature", which includes "not merely things and their forces, but men and their ways and the fashioning of the affections and of the will into an earnest and loving desire to move in harmony with those laws." He further describes a liberally educated man as one "who has been so trained in youth that his body is the ready servant of his will, and does with ease and pleasure all the work that, as a mechanism, it is capable of; whose intellect is a clear, cold, logic engine, with all its parts of equal strength, and in smooth working order; ready, like a steam engine, to be turned to any kind of work, and spin the gossamers as well as forge the anchors of the mind; whose mind is stored with a knowledge of the great and fundamental truths of Nature and of the laws of her operations; one who, no stunted ascetic, is full of life and fire, but whose passions are trained to come to heel by a vigorous will, the servant of a tender conscience; who has learned to love all beauty, whether of Nature or of art, to hate all vileness, and to respect others as himself" [20, n.p.].

In modern societies education has turned servile. It is viewed as a "wealth creation process" [17, p.91]. The entire focus is on gaining intelligence in order to make a living rather than developing an intellect. There is no provision to pause, think, analyze and come to independent conclusions. Hence, information acquired from the external sources remains undigested, hardly assimilated. Such knowledge does not last. Moreover, the human intellect remains weak and dull.

Not only secular education but also spiritual education is undertaken with a servile attitude. Spirituality is sought to provide material benefit, emotional solace and intellectual satisfaction. Hardly anyone approaches spirituality liberally, seeking out the eternal truths of life. Spiritual education today consists mainly of memorizing scriptural texts, hardly understanding their essence. The entire emphasis is on scholastic education. Thus, spiritual education has become a rigid and mechanical process dictated by doctrine and dogma. Bereft of systematic study and research, reflection and contemplation upon the truths of life, servile education stifles spirituality and promotes dogmatism.

Reasoning and free enquiry are the main principles of liberal spiritual education. When these principles are followed, there is little room for blind adherence to dogmas and tenets. Bertrand Russell observed that, "It is only in a spirit of free enquiry that desirable learning can take place. In this kind of atmosphere students are not compelled to believe in tenets, but only in evidence which is objective" [18, p.74]. Hence, a liberally educated person rejects any idea which is not well-founded and does not stand the test of reason.

Liberal spiritual education inculcates three distinct processes: shravana or listening, manana or reflection and nididhyaasana or experience. At the initial stage, a student gains information on spiritual truths by listening to masters or reading the scriptures. However, spiritual education is not measured by the number of lectures heard or books studied, but by the depth of one's study. A person may be well-versed in scriptural literature, yet not turn spiritual. All the sacred knowledge that one gathers would fail to bring about a transformation of one's personality without reflection. In reflection one exercises the intellect to verify the authenticity of information received and to gain deeper understanding of the truths of life. Reflection and contemplation are necessary to assimilate, digest the information gained from books and discourses. Through the process of reflection spiritual values become one's own. Thereafter, one enters into the final stage of spiritual education, nididhyaasana, whereby one lives, applies the knowledge.

The procedure of shravana, manana and nididhyaasana must be followed methodically. A. Parthasarathy describes spiritual education as "a technology far more scientific than any other known in the world" [3, p.260]. He further elucidates that "there is a greater system and more rigorous discipline associated 
with the spiritual courses. The procedures laid down in them are far more exacting. You will have to follow them meticulously like the other sciences" [3, p.260].

Liberal education establishes a scientific approach to spirituality. It enables one to sift evidence and analyze facts, to discriminate between the true and the false, the real and the unreal. Such education takes one methodically from the known to the unknown. The same approach is used with respect to science or mathematics wherein facts are not accepted on sheer authority, but through verification of their authenticity.

Spiritual education must be undertaken in regulated doses. The best time to reflect and contemplate on the spiritual truths is $4-6 \mathrm{am}$. It is the time when the mind is calm and composed. Therefore, most receptive. While reflecting upon a portion of a scripture a student may ask himself the following questions: How do I know that? Can I prove it? What is the evidence? What are the practical examples from life?

Questioning is the fundamental principle of liberal spiritual education. Being grounded in logic and rationality, facts and evidence, questioning is distinct from baseless doubting and skepticism. This would provide a practical means of eliminating authoritarian and dogmatic belief systems. A spirit of healthy questioning cures dogmatism. It ensures that knowledge is taken on its own merit, rather than on authorities.

A seeker's intellect trained by applying the above methods becomes strong and sharp. A person with a developed intellect gains spiritual maturity, wisdom. The characteristics of a spiritually educated individual are open-mindedness and objectivity. An open-minded person remains vigilant against any bias or prejudice. $\mathrm{He}$ possesses humility and a genuine desire to learn. He has an outlook of friendliness towards the world. His intellect is always available for examining and assessing people and situations at every step. Such a person is objective, i.e. uninvolved and unattached to his own views or ideas. As a result, he is tolerant and forgiving towards all. Newman describes a liberally educated person as a "friend of religious toleration, and that, not only because his philosophy has taught him to look on all forms of faith with an impartial eye, but also from the gentleness and effeminacy of feeling, which is the attendant on civilization" [19, p.160].

Hence, liberal spiritual education eradicates dogmatic closed-mindedness, arrogance and resistance to learning by developing the human intellect. A fortified intellect saves societies from the negative consequences of dogmatism such as intolerance, conflicts and destruction.

\section{Conclusion}

Spirituality per se does not cause dogmatism. Dogmatism arises when spirituality is in decline due to neglect of the intellect. As a result, the living knowledge of the scriptures and the truths embedded therein is superseded by mechanical ritual, blind belief, superstition and dogma.

Dogmatism and spirituality are mutually exclusive terms. Spirituality is founded on eternal truths, dogmatism on opinions. The universalism of spirituality is directly opposed to dogmatic separatism and compartmentalization. Spirituality fosters a sense of unity and oneness amongst beings whereas dogmatism engenders social alienation and exclusive identity.

Spirituality is scientific and methodic, dogmatism undiscerning and irrational. Spiritual path requires individual effort, independent inquiry and contemplation. Dogmatism is characterized by following the herd instinct and unreasonable reliance on authorities.

Spirituality is liberal and humanistic, dogmatism is rigid and authoritarian. The attributes of a spiritually evolved person are open-mindedness and a willingness to learn whereas a dogmatic person is closedminded and opposed to new ideas. A person who has gained higher values is objective and tolerant. Hence, he lives at peace with oneself and harmony with others. A dogmatic person is prejudiced, socially alienated and aggressive. He conflicts with, threatens or ostracizes others. He is prepared to fight and destroy those who do not conform to his belief system.

Dogmatism and its manifestations remain major obstacles to human advancement, material as well as spiritual. Denial of freedom of thought, clannishness, authoritarianism, sectarianism and fanaticism bring about intellectual and spiritual stagnation, failure in inter-personal relationships, alienation and animosity, destructiveness and conflict. A. E. Mander states: "Propositions which are accepted blindly, without question, on the grounds of mere assumption or dogma, need to be frankly recognized as such. Progress in human thought seems to consist mainly in getting rid of such ideas" [7, p.30].

In order to eradicate dogmatism, a liberal approach to spiritual and secular education must be encouraged. Educational institutions must shift the focus of attention from gaining intelligence to the development of the intellect. A person educated liberally can apply his intellect in material as well as spiritual fields for gaining success and inner peace. A person with a strong intellect cannot succumb to closedmindedness and rigidity. The sharp intellect understands that "the truly religious, spiritual are those who rise above personal desires and pursue the supreme Self within. They steadfastly use religion, religious texts and practices to seek the Self. Maintain their objectivity and religious tolerance without falling prey to fanatic attachment to a particular religion" [21, p.52]. 
This paper did not investigate current trends in theological research that are similarly working to divest religious theory and practice of dogmatism. Identifying such trends and areas of conceptual agreement would help to establish constructive dialogue between theology and disciplines such as philosophy and individual \&social psychology. This would help to invalidate outmoded and harmful ways of approaching religion.

As intellectual development is the primary focus in the eradication of dogmatism, further research should thus investigate intellectual development. A range of issues arise in this regard. Among them: uncovering the most effective methods for intellectual development; implications for of short- and long-term policy changes required at national and local government levels; how institutions would implement development practices into school curricula, what this would cost schools and communities, and what it would mean for the training of teachers.

\section{References}

[1] M. Dillon, in B.S. Turner (Ed.), The Sociology of Religion: The New Blackwell Companion to Social Theory (West Sussex: Blackwell Publishing Limited, pp. 409 - 427, 2009)

[2] B.J. Zinnbauer, K.I. Pergament, B. Cole, M.S. Rye, E.M. Butter, T.J. Belavich, K.M. Hipp, A.B. Scott, \& J.L. Kadar, Religion and Spirituality: Unfuzzing the Fuzzy, Journal for the Scientific Study of Religion, 36(4), 1997, 549-564

[3] A. Parthasarathy, Vedanta Treatise: The Eternities (Mumbai: A. Parthasarathy, 2004)

[4] J.S. Larson, The World's Health Organization's Definition of Health: Social versus Spiritual Health, Social Indicators Research, 38(2), 1996, 181-192

[5] Palgrave Macmillan Dictionary of Political Thought, In Palgrave Macmillan Dictionary of Political Thought (2007) Retrieved from http://www/credoreference.com.proxy.globethics.net/entry/macpt/palgrave macmillan dictionary_of political-thought

[6] D. H. Swindell and L. L'Abate, Religiosity, Dogmatism and Repression Sensitization, Journal for the Scientific Study of Religion 9(3), 1970, 249-251

[7] A.E. Mander, Clearer Thinking (London: Watts \& Co., 1983)

[8] N.S. Xavier, Two Faces of Religion. A Psychiatrist's View (Bangalore: Theological Publications in India, 1998)

[9] M. Rokeach, The Nature and Meaning of Dogmatism, Psychological Review 61(3), 1954, 194-204

[10] J.M. Seaman, B.M. Jerry \& R.C. Dillehay, Membership in Orthodox Christian Groups, Adjustment and Dogmatism, The Sociological Quarterly, 12(2), 1971, 252-259

[11] Encyclopedia of Community, In Encyclopedia of Community (2003) Retrieved from http://www/credoreference.com.proxy.globethics.net/entrysagecommun/encyclopedia_of_community

[12] A. Parthasarathy, Bhagavad Gita (Mumbai: A. Parthasarathy, 2008)

[13] V. Bhushan and D. R. Sachdeva, An Introduction to Sociology (Allahabad: Kitab Mahal, 2003)

[14] M. Wakefield Understanding Scientology Retrieved from http://www.cs.cmu.edu/ dst/Library/Shelf/wakefield/us.html (Original work published 1991)

[15] W. Nicholls, Saints and fanatics: The problematic connection between religion and spirituality. Judaism, 45(4). 1996, 446-461

[16] Partnership for $21^{\text {st }}$ Century Skills, Learning for the $21^{\text {st }}$ Century: A Report and Mile Guide for $21^{\text {st }}$ Century Skills Retrieved from http://www.p21.org/storage/images/stories/otherdocs/p21up_Report.pdf

[17] A. Parthasarathy, The Fall of the Human Intellect (Mumbai: A. Parthasarathy, 2007)

[18] R. E. Egner, Bertrand Russell's Best (London: George Allen \& Unwin Ltd., 1971)

[19] J. H. Newman, The Idea of A University (Notre Dame: University of Notre Dame, 1986)

[20] T.H. Huxley, A Liberal Education http://www.wwnorton.com/college/english/nael/noa/pdf/27636_Vict_U12_Huxley.pdf Original work published 1868)

[21] A. Parthasarathy, Governing Business and Relationships (Mumbai: A. Parthasarathy, 2010) 